\title{
Development Research of Transnational Higher Education
}

\author{
Na Yang ${ }^{1, ~ a ~}$ and Miao Shang ${ }^{1, b}$ \\ ${ }^{1}$ Mechanical and Electrical Technology Department, Xijing University, Xi'an, China \\ a515569778@qq.com, ${ }^{\mathrm{b}} 445700839 @ q q . c o m$
}

Keywords: Transnational education; Economic globalization; High education; Global education

\begin{abstract}
Transnational higher education as an important form for internationalization of higher education in a global scale. Economic globalization promotes the deepening development of internationalization of higher education. In this article, transnational higher education is introduced; Development research of higher education is discussed in foreign countries; The development research of higher education is described in China; The development of transnational higher education is described. Finally, points out that: Cross-border higher education research is a must for our country. Cross-border higher education as a importer in China, and cross-border education is an important means to strengthen the construction of the ability. Transnational higher education is conducive to the development of higher education in our country, and transnational higher education is more conducive to the economic development of China. The development of higher education should choose internationalization of the road. At the same time, our country need to make contribution to the education development of the global higher education and economic development.
\end{abstract}

\section{Introduction of Transnational Higher Education}

Economic globalization driven by higher education internationalization continue to deepen. Transnational higher education into a global era of the development of higher education in the basic option [1]. The establishment of the Alliance for the Transnational Education represents a Transnational Education officially entered the education research areas. China is the largest developing country in the world and one of the fastest economic growth rates. In recent decades, Higher Education has achieved remarkable success. The development of the global economy, higher education has gradually become a potential development prospects of Transnational Education market. As a result, implementation has been achieved remarkable progress. Sino-foreign co-sponsoring become an important component of higher education in China.

Higher education is a transnational economic globalization - Higher Education internationalization - Transnational Higher Education -foreign cooperative sponsoring this relationship an important link in the chain. Economic globalization is both transnational the source for higher education of its occurrence and development background of the times [2]. Economic globalization to promote internationalization of higher education has further deepened. Economic globalization is underscoring transnational higher education of the times. In the establishment of the WTO in that trade in education services that allow transnational higher education is a regular road of development. Transnational higher education gradually demonstrated its own development.

Transnational higher education as a form of trade in services in a wide range of global development. Transnational higher education in China's practice to implementation, in which it is incurred in the course of development and to demonstrate the typical characteristics and accumulated a wealth of experience [3]. At the same time, higher education has also revealed that transnational many serious problems. School pattern to school system, investment system as well as management system influence decision transnational higher education. Distribution of science and technology cooperation object of university is shown in Fig. 1 


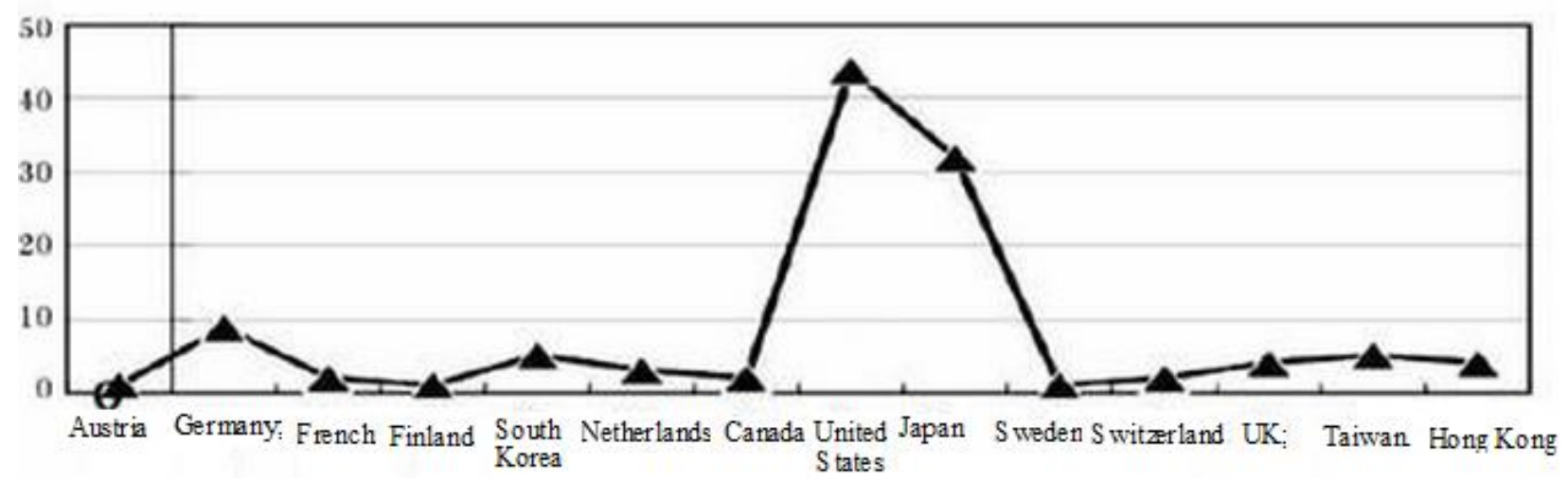

Figure 1. Distribution of science and technology cooperation object of university

\section{Development of Higher Education Sector in Abroad}

Transnational higher education as a form of trade in services in a wide range of global development. Transnational higher education is in higher education on the basis of internationalization [4]. The establishment of the Alliance for the Transnational Education represents a Transnational Education officially entered the education research areas. Transnational educational research from the outset with the international, regional and national bodies such as, at the various levels of the Organization's attention and involvement. Overseas scholars to transnational higher education research is mainly at the organizational level, and of the large number of study.

Economic globalization is both transnational the source for higher education of its occurrence and development background of the times. In its changing rationales for the internalization of higher education", hans de wit that higher education internationalization is internationalized and cross-cultural dimension into teaching, scientific research and institutional services features in process [5]. Transnational higher education was considered to be an international process. Transnational higher education to globalization as a reaction to the. Transnational higher education will higher education as a commodity exports and given more attention.

\section{Development of Higher Education Sector in National}

The development of higher education in the promotion of the cause of China's education development, while the development of the higher education sector is also facilitated by the rapid economic development of our country. Higher education in our country have transnational of more research [6]. As part of the national "transnational educational research staff of the week, professor, he within the trade in education services to cross-border education, was conducting a referral. States cross-border education in form, cross-border education-related concepts and policy objectives as well as the cross-border education development in the diversification has different characteristics. Norway's "International trade in education services forum." The important results can be summarized as follows: (1) The cross-boundary education" concept is the replacement of the concept of trade in education services; (2) participation in the form of participation in personnel (including students and teachers), projects, institutions of the cross-border movement. The goal of education for cross-boundary is not only for the economic benefits that get more is to enhance between state and state of mutual understanding, developing human resources and strengthening capacity-building. Cross-border higher education research is essential for my country [7]. As part of the cross-border higher education in importing countries need to cross-border education as part of the strengthening of the capacity-building of the important means.

In the higher education Internationalization: from political influence to services trade", the related impact of the higher education is described. These elements include: Internationalization of higher education to expand their political influence from the stage of history to emerge from its economic crisis period, through education, economic circles to jointly promote the building of international 
trade in education services, as well as the current trade in education services to the new forms of trade in education services, the developmental path of Â Global Education Services". My country, as the world's largest importer of education" and the "maximum of trade in education services market to be a level of preparedness and response measures [8]. Professor Chang elected in the product of trade in education services: "No boundaries" Higher Education" on the "borderless" higher education meaning and its type, as well as the "borderless" higher education trend. Professor Yu Fruit in the Higher Education of the international dimension of the development and evolution of the term in the text analysis of causes the Internationalization of Higher Education" is the term used to ambiguities causes, as well as the international dimension of the trends and derived a series of related terms and discerning the meaning of these concepts, differences with the contact. Where "Internationalization of Higher Education" is the most comprehensive "cross-border education" is one of the ingredients of internationalization, while "Education trade" as well as "cross-border education".

\section{Development of Higher Transnational Education}

For nearly 30 years, transnational higher education as a higher education internationalization of an important form in a global context very fast development, there are a number of concepts used to describe this phenomenon. In actual use, only a "Transnational Higher Education", the borderless, "overseas tertiary education", "cross-border higher education" several terminology comparisons commonly found in UNESCO and several national policies in the context of several other terms used only for a relatively small part of the research scholars. Transnational higher education, higher education overseas, Borderless Higher Education, cross-border higher education still has a different application.

The former two are normally only used to refer to non-indigenous international education project; Borderless Higher Education because of its scope of application included a variety of borders and overly broad general in higher education is only used to remote and online education; and cross-border higher education term include bidirectional i.e. input and output, and respect for the sovereignty of States which could be more accurately convey the transnational HIGHER EDUCATION" this phenomenon. Transnational higher education by natural factors and external power factors [9]. Natural factors referred to individual/institutions/organizations/bodies from some of the differences in the impact of non-ready to work with the transnational flow of higher education with economic disparities, cultural differences, political differences and disparities in education; external power factors referred to individual/homes in organizations/bodies/project of an external push for the transnational movement of higher education included political forces to promote, various organizations in the promotion of economic interest to promote regional integration, such as the promotion. Natural Factors and the individual is attracted by the flow of the main factors that external power factor is the institutions and projects of the international movement of the main engine of institutions and projects flow is flow of transnational higher education subjects. Transnational higher education in the worldwide practice to diversify [10].

At present, the major exporting countries focused more on quality of higher education was the security and the emerging higher education-exporting countries focused more on projects and the number of students of growth. In Australia and China, for example, Australia's overseas item quantity due to quality control and the UK higher education to enhance competitiveness of output decline. China entered the transnational education" concept is mainly to "THN", many academics would "THN" and "implementation" on an equal footing and is incorrect readings. At present, China is not targeted at China Higher Education output under the relevant laws. The United Nations Educational, Scientific and Cultural Organization in 2004, the cross-border higher education quality guidelines, the purpose of which is to protect students and other interested parties from the School quality is poor or the violation of a school, some European and American countries have taken action to safeguard the quality of higher education transnational. China for "transnational" concept of higher education have 
different views that it is not yet make appropriate selection, the need for the Government to enter the education and output the education and manpower planning, development.

\section{Conclusions}

The development of higher education in the promotion of the cause of China's education development, while the development of the higher education sector is also facilitated by the rapid economic development of our country. Higher education: transnational as an important form of Internationalization of higher education very fast development on a global scale. Economic globalization driven by higher education internationalization continue to deepen. In this article, transnational higher education was made a basic introduction to the development of higher education; the study was carried out on the development of higher education; research in the country was carried out; the development of higher education in transnational is described. Finally pointed out that in conducting cross-border higher education research is essential for my country. My country, as cross-border higher education in importing countries need to cross-border education as part of the strengthening of the capacity-building of the important means. Transnational higher education to the development of the higher education sector will benefit China, which are more conducive to the development of our country's economy. Our higher education should take the path of internationalization, and the road of development of higher education at the same time my need to make a contribution to the global educational advancement and economic development.

\section{References}

[1] Henry m. levin. Education How to Adapt to Future-Background of American Education, Peking University Education Review, Vol. 2 (2013), p. 2-3.

[2] H.Y.Liu: U DP Proportion Higher Education and Social Policy Research, Vol. (2012), P. 27-28.

[3] B.C.Ji:Our Country's Higher Education Scale Forecast Analysis in 2020, Vol. 1 (2011) No. 1, p. 305.

[4] Verbik L, Merkley C: Intematinal Branch Campus - Models and Trends, Observatory on Borderless (Higher Education Report, China, 2006).

[5] L.J.Guo: Under Globalization of Transnational Higher Education -Point of View, Problems and China's Response (China Social Sciences Press, China, 2009)

[6] G.S.Yi: University Chinese-Foreign Cooperation in Running Schools Mode and Operation Mechanism of Research (Shanghai University Publishing House, China 2007.)

[7] Benoit Minogue: Higher Education Spending and Output-Complexity of Relationship, Peking University Education review, Vol. 2 (2013), 60.

[8] J.B.Wang, H.T.Yang: New Field of Overseas Investment-New Trend of Transnational Higher Education (DongYue Review, China, 2012)

[9] Y.L.Xie: Soul of European Universities Classification, Comparative Education Research, Vol.4 (2010), p. 45.

[10] G.P.Feng: Transnational Education-International Comparative Study (Shanghai People's Publishing House, China, 2010) 